\title{
Studies on Coordination Chemistry and Antibacterial Activity of Bidentate NS Schiff Base Derived From SBDTC and 4-Benzyloxybenzaldehyde
}

\author{
M. H. $\operatorname{Islam}^{1 *}$, M. C. Sheikh ${ }^{2}$, M. A. A. A. A. Islam ${ }^{1}$ \\ ${ }^{1}$ Department of Chemistry, Rajshahi University of Engineering \& Technology, Rajshahi-6204, \\ Bangladesh \\ ${ }^{2}$ Department of Applied Chemistry, Faculty of Engineering, University of Toyama, 3190 Gofuku, \\ Toyama 930-8555, Japan
}

Received 13August 2018, accepted in final revised form 21October 2018

\begin{abstract}
The condensation of 4-benzyloxybenzaldehyde with S-benzyl dithiocarbazate (SBDTC) in absolute ethanol afforded the Schiff base, S-benzyl- $\beta-N$-(4-benzyloxyphenyl)methylenedithiocarbazate (1). The ligand on further reaction with metal ions in absolute ethanol [for $\mathrm{Ni}(\mathrm{II}), \mathrm{Cu}(\mathrm{II}), \mathrm{Zn}(\mathrm{II})]$ and in methanol [Pd(II)] resulted in the formation of the corresponding four coordinate complexes. The ligand and its complexes were characterized by physico-chemical techniques, viz., molar conductance, magnetic susceptibility measurement, IR, NMR and solution UV/Vis spectroscopic techniques. The complexes demonstrated stronger antibacterial activity than the free ligand indicating that coordination with these metal ions has enhanced biological potential of the ligand. All the compounds exhibited more or less moderate activity against the test organisms.
\end{abstract}

Keywords: SBDTC Schiff base; Metal complexes; Antibacterial activity.

(C) 2019 JSR Publications. ISSN: 2070-0237 (Print); 2070-0245 (Online). All rights reserved. doi: http://dx.doi.org/10.3329/jsr.v11i1.37863

J. Sci. Res. 11 (1), 121-132 (2019)

\section{Introduction}

Dithiocarbazic acid was first synthesized by Curtius[1]. Since then, considerable number of S-alkyl/aryl-esters, the Schiff bases of such compounds and of their corresponding complexes have been prepared and investigated for biological applications such as antibacterial, anticancer, antifungal, antitumor [2-6], antiamoebic [7-9] and antiinhibitory cell migration activities [10] or simply for the different coordination geometry [2,11-13]. Besides the medicinal applications, complexes derived from dithiocarbazate esters and their Schiff bases have also possible applications in the area of electronic engineering as nano-materials [14], solar cell components [15] and non-linear optical materials (NLO)

\footnotetext{
*Corresponding author:mhislamchem.bsfic@gmail.com
} 
[16]. Dithiocarbazates constitute one of the most important classes of mixed hard-soft nitrogen-sulfur donor ligands [2,17], having four potential donor atoms of which two are sterically available at a time to chelate metal ions. In fact the presence of hard nitrogen and soft sulfur atoms enable these ligands to react with both transition and main group metals [18]. In principle both NS (Nitrogen-sulfur) and SS (Sulfur-sulfur) complexes are feasible (Scheme 1). Free dithiocarbazaic acid and its S-benzyl esters behave typically as NS donorswith formation of a five-membered chelate ring [14,18,19], but SS coordination was also observed making a four-membered chelate ring [19]. However, a change of suitable groups at hydrazine moiety of these compounds can modify the donor sequence of such ligands giving rise to different coordination geometries [2,20-23]. The present work represents the coordination behavior of S-benzyl- $\beta-\mathrm{N}-(4-$-benzyloxyphenyl) methylene hydrazine carbodithioate with some transition metal ions and study of their antibacterial activities.

\section{Experimental}

\subsection{Materials and instrumentation}

All the chemicals and solvents were of reagent grade and used without further purification. Hydrazine hydrate $(90 \%)$, carbon disulfide and potassium hydroxide were purchased from Merck (India) while benzyl chloride was obtained from Sisco Research Laboratories (SRL) Pvt. Ltd, India. The metal salts: nickel(II) acetate tetrahydrate, copper(II) acetate monohydrate and zinc(II) acetate dehydrate and palladium(II) chloride were obtained from FlukaChemica (Switzerland). Solvents: chloroform, ethanol, toluene, acetonitrile and DMSO (dimethyl sulfoxide) were obtained from Active Fine (Bangladesh). The ligand precursor, 4-benzyloxybenzaldehyde (BOB) was prepared following the literature procedure [24]. IR spectra (4000-400 $\left.\mathrm{cm}^{-1}\right)$ were obtained as $\mathrm{KBr}$ pellet using IR Affinity 1S spectrometer, (Shimadzu, Japan) from the Department of Chemistry, RUET (Rajshahi University of Engineering \& Technology). ${ }^{1} \mathrm{H}$ NMR (0-14 ppm, $500 \mathrm{MHz})$ and ${ }^{13} \mathrm{C}$ NMR $(0-200 \mathrm{ppm}, 125 \mathrm{MHz})$ spectra were recorded on a JNMA500 spectrometer in $\mathrm{CDCl}_{3}$ and $\mathrm{d}_{6}$-DMSO using TMS (tetra methyl silane) as internal standard at the Department of Applied Chemistry, University of Toyama, Japan. Magnetic susceptibility and molar conductance measurements were made on a magnetic susceptibility balance (Sherwood Scientific, UK) and molar conductance measurements with a heavy-duty conductivity/temperature meter (Extech Instruments, USA, model No. 407303), at the Department of Chemistry, RUET. The UV-visible absorptions were scanned on a T60 UV-visible spectrophotometer (PG Instruments, UK) between 200-1100 $\mathrm{nm}$ in $10^{-5} \mathrm{M}$ solution of DMSO at the Department of Chemistry, Rajshahi University of Engineering \& Technology (RUET) using Win5 software. 


\subsection{Synthesis of 4-benzyloxybenzaldehyde as ligand precursor}

A mixture of 4-hydroxybenzaldehyde $(12.2 \mathrm{~g}, 100 \mathrm{mmol})$ and benzyl bromide $(17.1 \mathrm{~g}$, $100 \mathrm{mmol})$ was refluxed in of acetone $(100 \mathrm{~mL})$ for $30 \mathrm{~h}$ in presence of anhydrous potassium carbonate $(20 \mathrm{~g})$. Then solvent was evaporated and the product was extracted from a mixture water and dichloromethane. Finally the product was purified by column chromatography using dichloromethane as mobile phase. After complete evaporation of solvent, an off white solid was obtained. (yield: $13 \mathrm{~g}, 44 \%$, m.p. $71.5^{\circ} \mathrm{C}$ (Lit. $72{ }^{\circ} \mathrm{C}$ ).

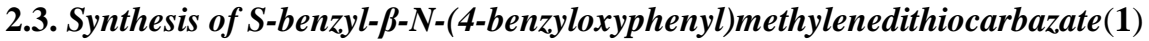

4-benzyloxybenzaldehyde (1.96 g, $10 \mathrm{mmol})$ in ethanol $(25 \mathrm{~mL})$ was added to a boiled solution of S-benzyldithiocarbazate $(1.98 \mathrm{~g}, 10 \mathrm{mmol})$ in ethanol $(40 \mathrm{~mL})$ and the mixture was refluxed for $1 \mathrm{~h}$. The white solid which formed was separated by filtration and recrystallized from methanol as white crystalline solid (Fig. 1). Yield: $3.74 \mathrm{~g} \mathrm{(95 \% ).} \mathrm{m.p.}$ $140^{\circ} \mathrm{C}$. Selected IR data $\left(\mathrm{KBr}\right.$ pellet, $\left.\mathrm{cm}^{-1}\right)$ v: $3111 \mathrm{~m}(\mathrm{~N}-\mathrm{H}), 3030 \mathrm{w}(\mathrm{C}-\mathrm{H}$ aro. $), 2978 \mathrm{~m}$, 2854w (C-H, aliphatic), 1502vs $(\mathrm{C}=\mathrm{N}), 1597 \mathrm{~s}(\mathrm{C}=\mathrm{C}$, aromatic ring), 1255vs (C-O), $1165 \mathrm{~s}(\mathrm{C}-\mathrm{N}), 1094 \mathrm{~s}(\mathrm{C}=\mathrm{S}), 1020 \mathrm{~s}(\mathrm{~N}-\mathrm{N})$, others: 1452ms, 1333s, 1298s, 1221s, 825s, 744s, 698s. UV-vis spectrum $\left[\lambda_{\max }, \mathrm{CHCl}_{3}, \mathrm{~nm}(\log \varepsilon)\right.$ : 256 (4.76), 276 (4.82), 321 (4.52), 389 (3.76). ${ }^{1} \mathrm{H}$ NMR (400 MHz, $\left.\mathrm{CDCl}_{3}, \mathrm{ppm}\right) \delta$ : 4.55 (s, $\left.2 \mathrm{H} \mathrm{SCH}_{2}\right), 5.09$ (s, 2H, $\mathrm{CH}_{2} \mathrm{O}$ ), 7.635 (d, 2H, J =8.8 Hz, $\left.\mathrm{C}_{6} \mathrm{H}_{4}-\mathrm{H}-2,6\right), 6.97$ (d, 2H, J= $\left.8.8 \mathrm{~Hz}, \mathrm{C}_{6} \mathrm{H}_{4}-\mathrm{H}-3,5\right), 7.40$ (m, 5H, $\left.\mathrm{PhH}-2^{\prime}, 3^{\prime}, 4^{\prime}, 5^{\prime}, 6^{\prime \prime}\right), 7.313$ (m, 5H, PhH-2", 3", 4', 5", 6"), 7.79 (s, 1H, $\left.\underline{\mathrm{CH}}=\mathrm{N}\right), 10.27$ (s, $1 \mathrm{H}, \mathrm{NH}) .{ }^{13} \mathrm{C} \mathrm{NMR}\left(100 \mathrm{MHz}, \mathrm{CDCl}_{3}, \mathrm{ppm}\right) \delta: 39.49\left(\mathrm{SCH}_{2}\right), 70.12\left(\mathrm{CH}_{2} \mathrm{O}\right), 145.09$ $\left(\mathrm{C}_{6} \mathrm{H}_{4} \mathrm{C}-1\right), 136.35$ (PhC-1'), 136.0 (PhC-1'), $129.59\left(\mathrm{C}_{6} \mathrm{H}_{4} \mathrm{C}-2,6\right), 129.49\left(\mathrm{PhC}-2^{\prime}, 6^{\prime}\right)$, 128.67 (PhC-2", 6"), $115.27\left(\mathrm{C}_{6} \mathrm{H}_{4} \mathrm{C}-3,5\right), 128.19$ (PhC-3', 5'), 128.63 (PhC-3", 5"), $125.71\left(\mathrm{C}_{6} \mathrm{H}_{4} \mathrm{C}-4\right), 127.47\left(\mathrm{PhC}-4^{\prime}\right), 127.47\left(\mathrm{PhC}-4^{\prime \prime}\right), 161.67(\mathrm{CH}=\mathrm{N}), 198.0(\mathrm{C}=\mathrm{S})$.

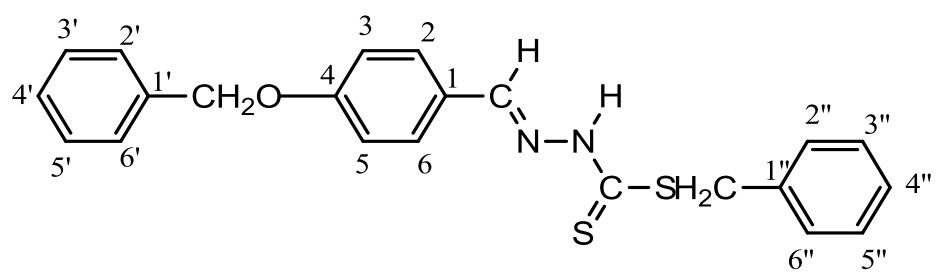

Fig. 1. S-benzyl- $\beta$-N-(4-benzyloxybenzyl)methylenedithiocarbazate.

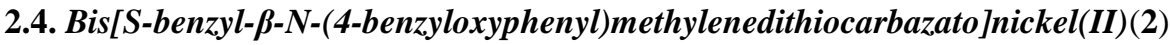

A solution of nickel(II) acetate tetrahydrate $(0.12 \mathrm{~g}, 0.5 \mathrm{mmol})$ in ethanol $(15 \mathrm{~mL})$ was added to a hot solution of the Schiff base $(0.392 \mathrm{~g}, 1.0 \mathrm{mmol})$ in ethanol $(40 \mathrm{~mL})$ and the aliquot was stirred under reflux for $0.5 \mathrm{~h}$. The brown precipitate, which formed, was filtered off and washed successively with hot ethanol and pet-ether $\left(40-60{ }^{\circ} \mathrm{C}\right)$ and finally dried in vacuum over anhydrous $\mathrm{CaCl}_{2}$. The compound was purified from a mixture of chloroform and toluene $(5: 1 ; \mathrm{v} / \mathrm{v})$ as brown crystalline solid after crystallization for 15 
days. Yield: $0.192 \mathrm{~g}(75 \%)$ m.p. $190{ }^{\circ} \mathrm{C}$. Selected IR data $\left(\mathrm{KBr}\right.$ pellet, $\left.\mathrm{cm}^{-1}\right)$ v: $3030 \mathrm{w}$ (C-H, aromatic), 1495s $(\mathrm{C}=\mathrm{N}), 1599 \mathrm{~s}(\mathrm{C}=\mathrm{C}$, aromatic), 1258s (C-O), 1171s (C-N), $1003 \mathrm{~ms}(\mathrm{~N}-\mathrm{N}), 503 \mathrm{w}(\mathrm{M}-\mathrm{N}), 410 \mathrm{w}(\mathrm{M}-\mathrm{S})$. Others: 967m, 881w, 829m, 704m. UV-vis spectrum $\left[\lambda_{\max }, \mathrm{CHCl}_{3}, \mathrm{~nm}(\log \varepsilon): 277\right.$ (4.38), 296 (4.22), 320 (3.77), 431-447 (2.62), 568 (2.32). ${ }^{1} \mathrm{H}$ NMR (400 MHz, $\left.\mathrm{CDCl}_{3}, \mathrm{ppm}\right) \delta: 4.35$ (s, 2H SCH ), 5.10 (s, 2H, $\left.\mathrm{CH}_{2} \mathrm{O}\right), 7.44$ $\left(\mathrm{d}, 2 \mathrm{H}, \mathrm{J}=8.8 \mathrm{~Hz}, \mathrm{C}_{6} \mathrm{H}_{4}-\mathrm{H}-2,6\right), 7.00\left(\mathrm{~d}, 2 \mathrm{H}, \mathrm{J}=8.8 \mathrm{~Hz}, \mathrm{C}_{6} \mathrm{H}_{4}-\mathrm{H}-3,5\right), 7.44$ (m, 5H, PhH$\left.2^{\prime}, 3^{\prime}, 4^{\prime}, 5^{\prime}, 6^{\prime \prime}\right), 7.33$ (m, 5H, PhH-2", 3", 4', 5", 6"), 7.56 (s, 1H, CH=N). ${ }^{13} \mathrm{C} \mathrm{NMR} \mathrm{(100}$ $\left.\mathrm{MHz}, \mathrm{CDCl}_{3}, \mathrm{ppm}\right) \delta$ : $38.36\left(\mathrm{SCH}_{2}\right), 70.12\left(\mathrm{CH}_{2} \mathrm{O}\right), 137.18\left(\mathrm{C}_{6} \mathrm{H}_{4} \mathrm{C}-1\right), 136.0\left(\mathrm{PhC}-1^{\prime}\right)$, 132.77 (PhC-1"), $129.0\left(\mathrm{C}_{6} \mathrm{H}_{4} \mathrm{C}-2,6\right), 128.71$ (PhC-2', 6'), 128.60 (PhC-2", 6"), 114.73 $\left(\mathrm{C}_{6} \mathrm{H}_{4} \mathrm{C}-3,5\right), 128.31$ (PhC-3', 5'), 127.66 (PhC-3", 5"), $127.62\left(\mathrm{C}_{6} \mathrm{H}_{4} \mathrm{C}-4\right), 124.85(\mathrm{PhC}-$ $\left.4^{\prime}\right), 124.85\left(\mathrm{PhC}-4^{\prime \prime}\right), 161.82(\mathrm{CH}=\mathrm{N}), 178.91(\mathrm{C}=\mathrm{S}) . \Lambda\left(\mathrm{CHCl}_{3}, 10^{-5} \mathrm{M}, \mathrm{ohm}^{-1} \mathrm{~cm}^{2} \mathrm{~mol}^{-1}\right)$ : $1.59 ; \mu_{\mathrm{eff}}$ : diamagnetic.

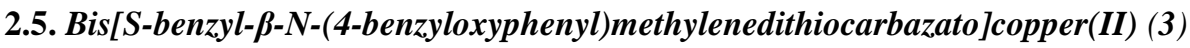

A solution of copper(II) acetate monohydrate $(0.1 \mathrm{~g}, 0.5 \mathrm{mmol})$ in ethanol $(20 \mathrm{~mL})$ was added to a hot solution of the Schiff base $(0.392 \mathrm{~g}, 1.0 \mathrm{mmol})$ in ethanol $(40 \mathrm{~mL})$ and stirred under reflux for $0.5 \mathrm{~h}$. The reddish brown precipitate, which formed, was filtered off and washed successively with hot ethanol and pet-ether $\left(40-60^{\circ} \mathrm{C}\right)$ and finally dried in vacuum over anhydrous $\mathrm{CaCl}_{2}$. The compound was obtained as reddish brown crystalline solid after crystallization from chloroform and acetonitrile $(5: 1 ; \mathrm{v} / \mathrm{v})$. Yield: $0.386 \mathrm{~g}$ (78\%). m.p. $165{ }^{\circ} \mathrm{C}$. Selected IR data $\left(\mathrm{KBr}\right.$ pellet, $\left.\mathrm{cm}^{-1}\right)$ v: $3028 \mathrm{mw}(\mathrm{C}-\mathrm{H}$, aromatic), 2928w, 2868w (C-H, aliphatic), 1470s $(\mathrm{C}=\mathrm{N}), 1599 \mathrm{~m}, 1583 \mathrm{~s}$ (C=C, aromatic), 1258s (CO), 1171vs (C-N), 1022m (N-N), 529m, (M-N), 412w (M-S), Others: 1560ms, 1502m, 1306w, 955m, 831m, 744m, 697ms. UV-vis spectrum [ $\lambda_{\max }, \mathrm{CHCl}_{3}, \mathrm{~nm}(\log \varepsilon): 237$ (3.89), 273 (4.14), 296 (3.87), 363 (2.26), 474 (3.91). $\Lambda\left(\mathrm{CHCl}_{3}, 10^{-5} \mathrm{M}, \mathrm{ohm}^{-1} \mathrm{~cm}^{2} \mathrm{~mol}^{-1}\right): 2.14$; $\mu_{\text {eff }}: 1.85$ B.M.

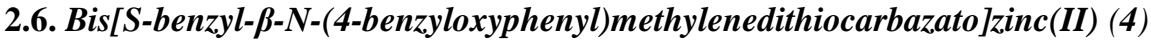

A solution of zinc(II) acetate dihydrate $(0.054 \mathrm{~g}, 0.25 \mathrm{mmol})$ in ethanol $(30 \mathrm{~mL})$ was added to a boiled solution of the Schiff base $(0.196 \mathrm{~g}, 0.5 \mathrm{mmol})$ in ethanol $(20 \mathrm{~mL})$ and stirred under reflux for $1 \mathrm{~h}$. The yellow precipitate which formed was separated by filtration, washed with hot ethanol and dried in vacuum over anhydrous $\mathrm{CaCl}_{2}$. The compound was purified in chloroform as light yellow crystalline solid. Yield: $0.203 \mathrm{~g}$ (81\%). m.p. $170{ }^{\circ}$ C. Selected IR data $\left(\mathrm{KBr}\right.$ pellet, $\left.\mathrm{cm}^{-1}\right)$ v: 3024w (C-H, aromatic), $1441 \mathrm{~s}(\mathrm{C}=\mathrm{N}), 1597 \mathrm{~s}(\mathrm{C}=\mathrm{C}$, aromatic), 1261s (C-O), 1176s $(\mathrm{C}-\mathrm{N}), 1043 \mathrm{~m}(\mathrm{~N}-\mathrm{N}), 527 \mathrm{~m}$, (M-N), 401w (M-S). Others: 1566m, 1504s, 1394m, 962m, 951m, 831m, 746m, 696m.

UV-vis spectrum $\left[\lambda_{\max }, \mathrm{CHCl}_{3}, \mathrm{~nm}(\log \varepsilon): 277\right.$ (4.60), 296 (4.39). ${ }^{1} \mathrm{H}$ NMR (400 MHz, $\left.\mathrm{CDCl}_{3}, \mathrm{ppm}\right) \delta: 4.56 \& 4.45\left(\mathrm{~s}, 2 \mathrm{H}, \mathrm{SCH}_{2}\right), 5.11,5.04\left(\mathrm{~s}, 2 \mathrm{H}, \mathrm{CH}_{2} \mathrm{O}\right), 8.16(\mathrm{~d}, 2 \mathrm{H}, \mathrm{J}=8.8$ $\left.\mathrm{Hz}, \mathrm{C}_{6} \mathrm{H}_{4}-2,6\right), 6.88\left(\mathrm{~d}, 2 \mathrm{H}, \mathrm{J}=8.8 \mathrm{~Hz}, \mathrm{C}_{6} \mathrm{H}_{4}-3,5\right), 7.60\left(\mathrm{~d}, 2 \mathrm{H}, \mathrm{J}=8.8 \mathrm{~Hz}, \mathrm{C}_{6} \mathrm{H}_{4}-2,6\right)$, $6.96(\mathrm{~d}, 2 \mathrm{H}, \mathrm{J}=8.8 \mathrm{~Hz}, 3,5), 7.45$ (m, 5H, 2 X PhH-2', 3', 4', 5', 6'), 7.34 (m, 5H, 2 X $\left.\mathrm{PhH}-2^{\prime \prime}, 3^{\prime \prime}, 4^{\prime \prime}, 5^{\prime}, 6^{\prime \prime}\right), 7.65$ (s, 1H, N=CH). ${ }^{13} \mathrm{C} \mathrm{NMR}\left(100 \mathrm{MHz}, \mathrm{CDCl}_{3}, \mathrm{ppm}\right) \delta: 36.80$, 
$36.60\left(\mathrm{SCH}_{2}\right) ; 70.24,70.13\left(\mathrm{CH}_{2} \mathrm{O}\right) ; 137.68,137.27\left(\mathrm{C}_{6} \mathrm{H}_{4} \mathrm{C}-1\right) ; 135.91,135.55\left(\mathrm{PhC}-1^{\prime}\right)$; 131.51, 131.45 (PhC-1"); 129.23, $129.15\left(\mathrm{C}_{6} \mathrm{H}_{4} \mathrm{C}-2,6\right) ; 128.71,128.65$ (PhC-2', 6'); 128.89, 128.51 (PhC-2", 6"); 115.10, $114.99\left(\mathrm{C}_{6} \mathrm{H}_{4} \mathrm{C}-3,5\right)$; 127.62, 127.58 (PhC-3', 5'); 127.44, 127.42 (PhC-3", 5"); $129.1\left(\mathrm{C}_{6} \mathrm{H}_{4} \mathrm{C}-4\right)$; 128.32, 128.29 (PhC-4'); 127.26, 127.14 $\left(\mathrm{PhC}-4^{\prime \prime}\right) ; 162.29,161.14(\mathrm{CH}=\mathrm{N}) ; 178.0(\mathrm{CSS}) . \Lambda\left(\mathrm{CHCl}_{3}, 10^{-5} \mathrm{M}, \mathrm{ohm}^{-1} \mathrm{~cm}^{2} \mathrm{~mol}^{-1}\right): 1.33$. $\mu_{\text {eff }}$ : diamagnetic.

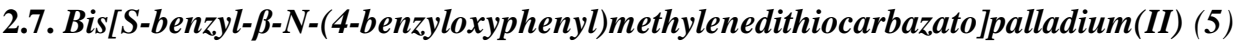

A solution of palladium(II) chloride $(0.044 \mathrm{~g}, 0.25 \mathrm{mmol})$ in methanol $(75 \mathrm{~mL})$ was added to a hot solution of the Schiff base $(0.196 \mathrm{~g}, 0.5 \mathrm{mmol})$ in ethanol $(30 \mathrm{~mL})$ and stirred under reflux for $0.5 \mathrm{~h}$. The orange precipitate, which formed, was filtered off, washed successively with hot ethanol and pet-ether $\left(40-60{ }^{\circ} \mathrm{C}\right)$. The compound was dried in vacuum over anhydrous $\mathrm{CaCl}_{2}$. Yield: $0.152 \mathrm{~g}(63 \%)$, m.p. $220^{\circ} \mathrm{C}$. Selected IR data $(\mathrm{KBr}$ pellet, $\left.\mathrm{cm}^{-1}\right)$ v: 3028w (C-H, aromatic), 1452s $(\mathrm{C}=\mathrm{N}), 1599 \mathrm{~s}(\mathrm{C}=\mathrm{C}$, aromatic), 1248s (CO), 1171s (C-N), 1024ms (N-N), 524w (M-N), 414w (M-S), Others: 1568s, 15410m, 943m, 825m, 735m, 694ms. UV-vis spectrum [ $\lambda_{\max }, \mathrm{CHCl}_{3}, \mathrm{~nm}(\log \varepsilon): 244$ (4.43), 273 (4.65), 533 (3.99), 571 (3.98), 619 (3.94); 659 (3.89). ${ }^{1} \mathrm{H}$ NMR (400 MHz, $\mathrm{CDCl}_{3}, \mathrm{ppm}$ ) $\delta: 4.40\left(\mathrm{~s}, 2 \mathrm{H} \mathrm{SCH}_{2}\right), 5.15$ (s, 2H, $\left.\mathrm{CH}_{2} \mathrm{O}\right), 7.48$ (d, 2H, J =8.0 Hz, $\left.\mathrm{C}_{6} \mathrm{H}_{4}-\mathrm{H}-2,6\right), 6.88$ (d, $\left.2 \mathrm{H}, \mathrm{J}=8.0 \mathrm{~Hz}, \mathrm{C}_{6} \mathrm{H}_{4}-\mathrm{H}-3,5\right), 7.46$ (m, 5H, PhH-2', 3', 4', 5', 6"'), 7.32 (m, 5H, PhH-2", 3", $\left.4^{\prime}, 5^{\prime \prime}, 66^{\prime \prime}\right), 7.62(\mathrm{~s}, 1 \mathrm{H}, \mathrm{CH}=\mathrm{N}) .{ }^{13} \mathrm{C} \mathrm{NMR}\left(100 \mathrm{MHz}, \mathrm{CDCl}_{3}, \mathrm{ppm}\right) \delta: 40.02\left(\mathrm{SCH}_{2}\right)$, $69.92\left(\mathrm{CH}_{2} \mathrm{O}\right), 145.90\left(\mathrm{C}_{6} \mathrm{H}_{4} \mathrm{C}-1\right), 140.0\left(\mathrm{PhC}-1^{\prime}\right), 134.23\left(\mathrm{PhC}-1^{\prime \prime}\right), 129.95\left(\mathrm{C}_{6} \mathrm{H}_{4} \mathrm{C}-2,6\right)$, 129.62 (PhC-2', 6'), 128.45 (PhC-2", 6"), $113.77\left(\mathrm{C}_{6} \mathrm{H}_{4} \mathrm{C}-3,5\right), 128.39$ (PhC-3', 5'), 128.16 (PhC-3", 5"), $127.77\left(\mathrm{C}_{6} \mathrm{H}_{4} \mathrm{C}-4\right), 124.77$ (PhC-4'), 126.88 (PhC-4"), 162.50 $(\mathrm{CH}=\mathrm{N}), 182.0(\mathrm{~N}=\mathrm{CSS}) . \Lambda\left(\mathrm{CHCl}_{3}, 10^{-5} \mathrm{M}, \mathrm{ohm}^{-1} \mathrm{~cm}^{2} \mathrm{~mol}^{-1}\right): 1.52 . \mu_{\text {eff }}$ : diamagnetic.

\section{Qualitative Antibacterial Assay}

The Schiff base (1) and its complexes (2-5) were assayed for antibacterial sensitivity against two gram negative (viz., E. coli, and $S$. dysenteriaei) and two gram positive ( $S$. lutea and $S$. aureous) bacteria. Antimicrobial activity was determined by disc diffusion method [25]. Briefly, a lawn of microorganisms was prepared by pipetting and evenly spreading $10 \mu \mathrm{L}$ of inoculums, adjusted turbidometrically to $10^{5}-10^{6} \mathrm{CFU} / \mathrm{cm}^{3}(\mathrm{CFU}=$ colony forming units) onto agar set in Petri dishes, using nutrient agar for the bacteria. Whatman No. 1 filter paper discs of $5 \mathrm{~mm}$ diameter were impregnated with dimethyl sulphoxide stock solution of the compounds. The stock solution was prepared by dissolving $8 \mathrm{mg}$ of each compound in $1 \mathrm{~mL}$ of DMSO. $200 \mu \mathrm{g}$ discs were prepared by soaking $25 \mu \mathrm{L}$ of the stock solution onto the filter paper discs using a $0.1 \mu \mathrm{L}$ sensitive micropipette. The dried dishes were then placed on previously inoculated agar surfaces. The plates were inverted and incubated for $24 \mathrm{~h}$ at $35 \pm 2{ }^{\circ} \mathrm{C}$ for the bacteria. Antibacterial activity was obtained from the diameter $(\mathrm{mm})$ of the inhibition zone in the discs. Kanamycin was used as standard drug for comparison. 


\section{Results and Discussion}

\subsection{Chemistry}

The reaction of 4-benzyloxybenzaldehyde with S-benzyl dithiocarbazate (SBDTC) afforded a Schiff base (1), which on subsequent reaction with metal ions in absolute ethanol [for $\mathrm{Ni}(\mathrm{II}), \mathrm{Cu}(\mathrm{II}), \mathrm{Zn}(\mathrm{II})$ ] and in methanol [Pd(II)] resulted in the formation of the corresponding four coordinated complexes (Scheme 1). All the compounds were soluble in non-coordinating organic solvents such as $\mathrm{CHCl}_{3}$, DMF, DMSO, THF etc. The room temperature molar conductance values at $10^{-5} \mathrm{M}$ solution of the complexes in $\mathrm{CHCl}_{3}$ are within the range of $1.52-6.2 \mathrm{ohm}^{-1} \mathrm{~cm}^{2} \mathrm{~mol}^{-1}$, suggested non-electrolytic nature of the complexes [26].

\subsection{IR spectra}

The IR spectra of the ligand and its complexes are reported in Fig. 2, where the Schiff base showed a medium intensity absorption band at $3111 \mathrm{~cm}^{-1}$, corresponding to the $v(\mathrm{~N}$ $\mathrm{H})$ stretching frequency that was absent in the complexes, suggesting that the ligand underwent coordination through the thiolate anion [27,28]. The Schiff base contained strong bands at 1502 and $1094 \mathrm{~cm}^{-1}$ for the $v(\mathrm{C}=\mathrm{N})$ and $v(\mathrm{C}=\mathrm{S})$ stretches, respectively [27-29]. The absence of $v(\mathrm{C}=\mathrm{S})$ band in the complexes also indicated thiolate binding with the respective metal ions in the complexes [27,28]. The $v(\mathrm{C}=\mathrm{N})$ band of the ligand was shifted to lower wave numbers $\left(\sim 7-61 \mathrm{~cm}^{-1}\right)$ in the complexes, suggesting its coordination through the azomethine nitrogen atom [26-28]. The stretching frequency of the $v(\mathrm{~N}-\mathrm{N})$ band, observed in the free ligand at $1020 \mathrm{~cm}^{-1}$, also shifted merely $\left(1043-1003 \mathrm{~cm}^{-1}\right)$ in the spectra of the complexes. This also supported the azomethine nitrogen bonding to the metal ions [26-28]. The ligand also showed a very strong band at $1255 \mathrm{~cm}^{-1}$ for the $v(\mathrm{C}-\mathrm{O}-$ C), which showed no significant change in the complexes [2]. The IR spectra of metal acetates show broad bands within the region of $1610-1520 \mathrm{~cm}^{-1}$ and $1420-1395 \mathrm{~cm}^{-1}$ for the asymmetric and symmetric stretching vibrations, predicting various modes of coordination with metal ions [30]. In the present study, both the ligand and its complexes exhibited sharp bands in these regions, as described above, suggesting the noninvolvement of acetate ion as coligand. 


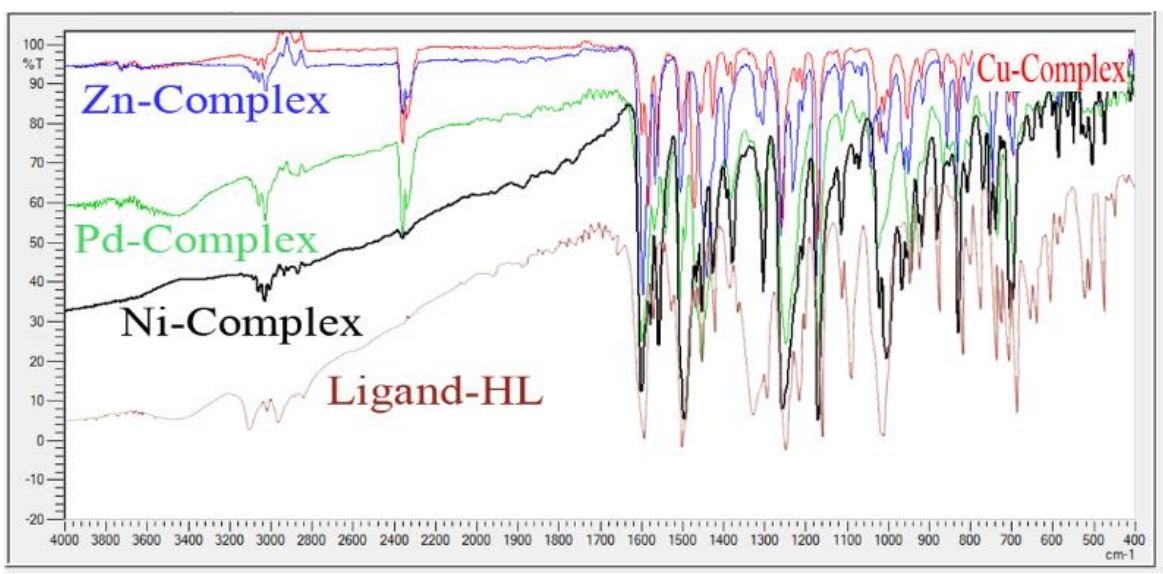

Fig. 2. IR spectra of ligand and its complexes as $\mathrm{KBr}$ pellet.

\subsection{NMR spectra}

The ${ }^{1} \mathrm{H}$ NMR of the ligand (1) showed a broad singlet at $10.27 \mathrm{ppm}$ assigned to the $(\mathrm{N}-\mathrm{H})$ proton [2,20,26-28]. Usually these species may exist in solution as an equilibrium mixture between the thione and thioltautomeric forms. It is worth noting that ligand (1) does not display any signal for the SH proton $(\sim 4.0 \mathrm{ppm})$, indicating the absence of the thiol form [2,20,26-28]. The absence of the NH signal in the ${ }^{1} \mathrm{H}$ NMR spectra of complexes (2, 4-5) indicated that the complexation occurred via deprotonation of this group [2,20,26-28]. The ligand had another singlet at $\delta 7.79$ for the azomithine proton [2,20,26-28], which was shifted to the up field in the complexes, validating it coordination through the azomethine nitrogen atom [2,20,26-28]. However, the singlet bands in the ligand for the $\mathrm{SCH}_{2}(\delta 4.55$ ppm) and $\mathrm{CH}_{2} \mathrm{O}(\delta 5.09 \mathrm{ppm})$ as well as the multiplet bands for the phenyl rings $(\delta 7.40-$ $7.30 \mathrm{ppm}$ ) showed no significant change in the complexes [2,20]. The ligand in its ${ }^{13} \mathrm{C}$ NMR spectrum showed resonances at ca. $\delta 198.91$ and $161.67 \mathrm{ppm}$ for the $\mathrm{C}=\mathrm{S}$ and $\mathrm{CH}=\mathrm{N}$ carbons respectively $[12,20,28]$, while in the complexes the former was shielded $(\delta \sim 178-182 \mathrm{ppm})$ [2,20,26-28]. These considerable shifts with respect to the ligand indicated the involvement of thiolate sulfur during coordination. However, the azomethine carbon atom showed no significant change in the complexes. Similarly, the $\mathrm{SCH}_{2}$, and $\mathrm{CH}_{2} \mathrm{O}$ carbons were observed in the free ligand at $\delta 39.49$ and $70.12 \mathrm{ppm}$ respectively $[2,20]$. Although the former was shielded, the later remain the same in the complexes. The resonance of phenyl carbons were reported in the experimental section.

\subsection{Solution electronic spectra}

The UV-visible spectra of all the compounds were scanned at $10^{-5} \mathrm{M}$ solution in DMSO and reported in Fig. 3. In the Fig. the Schiff base showed medium to strong intensity absorption bands at 256,276, 321 and $389 \mathrm{~nm}$, tentatively, assigned to the $\pi \rightarrow \pi^{*}$ (aromatic), $\pi \rightarrow \pi^{*}(\mathrm{CH}=\mathrm{N}), \mathrm{n} \rightarrow \pi^{*}(\mathrm{CH}=\mathrm{N})$ and $\mathrm{n} \rightarrow \pi^{*}$ (dithiocarbazate) transitions, 
respectively [31]. It was reported that similar ligands showed another band at $364 \mathrm{~nm}$ for the $\pi \rightarrow \pi^{*}$ (dithiocarbazate) transition [31]. However, this band was not observed in the present study, because it might be overlapped with the $n \rightarrow \pi^{*}$ (dithiocarbazate) transition. In the complexes, the $\pi \rightarrow \pi^{*}(\mathrm{CH}=\mathrm{N})$ band and the $\mathrm{n} \rightarrow \pi^{*}$ (dithiocarbazate) bands were blue shifted with reduction in intensity, as a result of coordination with the azomethine nitrogen and thiolate sulfur atoms respectively [32]. The nickel(II) and palladium(II) complexes showed a strong intensity band at 431 and $533 \mathrm{~nm}$ respectively, for the $\mathrm{S} \rightarrow \mathrm{M}$ charge transfer transition, indicating the coordination of the Schiff base to the metal atom via the thiolate sulfur [2,20,31]. Moreover, the nickel(II) complex showed another broad band at $568 \mathrm{~nm}$ for d-d band and the palladium(II) complex showed three bands at 571 , 619 and $659 \mathrm{~nm}$ (Fig. 5) for the ${ }^{1} A_{1 \mathrm{~g}} \rightarrow{ }^{1} A_{2 \mathrm{~g}},{ }^{1} A_{1 \mathrm{~g}} \rightarrow{ }^{1} B_{1 \mathrm{~g}}$ and ${ }^{1} A_{\mathrm{gg}} \rightarrow{ }^{1} E_{\mathrm{g}}$ transitions [2,20] respectively, consistent with square planar geometry. The solution electronic spectrum of $\mathrm{Cu}$ (II) complex was also investigated at $10^{-3} \mathrm{M}$ solution in order to detect its $\mathrm{d}$-d transitions, as reported in Fig. 4. As evident from the Fig., the compound displayed a weak intensity broad band centered at $820 \mathrm{~nm}$ with molar absorption co-efficient of 70 $\mathrm{Lmol}^{-1} \mathrm{~cm}^{-1}$, diagnostic to square planar $\mathrm{Cu}$ (II) [32], such transition is not normally observed for zinc(II) complex with $d^{10}$ configuration.

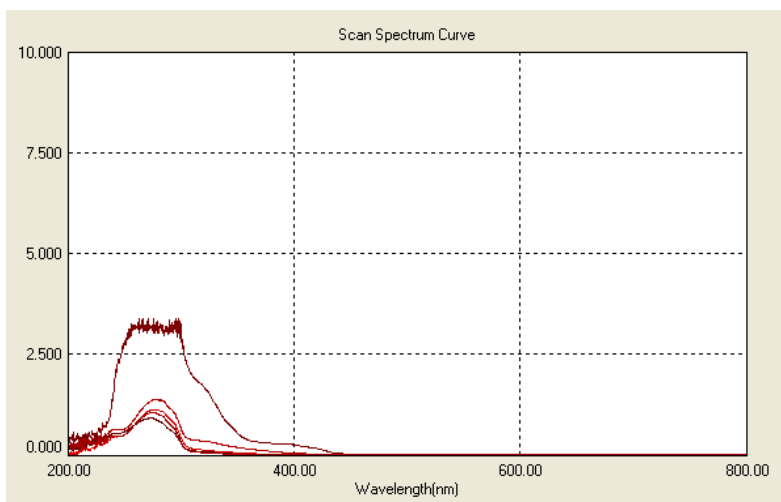

Fig. 3. The UV-visible spectra of the ligand (HL) and its complexes at $10^{-5} \mathrm{M}$ solution in chloroform.

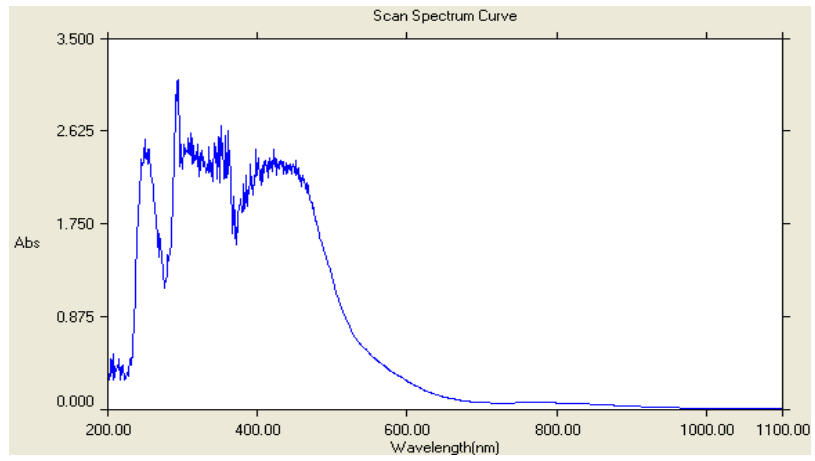

Fig. 4. UV-visible spectrum of copper(II) complex at $10^{-3} \mathrm{M}$ solution. 


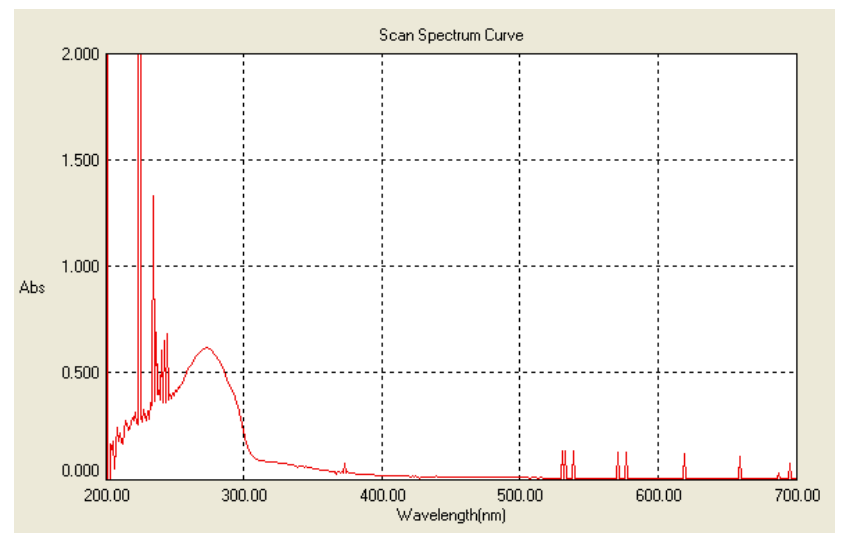

Fig. 5. UV-visible spectrum of palladium(II) complex at $10^{-5} \mathrm{M}$ solution.

\subsection{Qualitative antibacterial sensitivity}

The antibacterial sensitivity test of the complexes was studied against four pathogenic bacteria. The test results are depicted as the clear zone of inhibition in diameter $(\mathrm{mm})$ in Table 1 and their comparative activity is shown in Fig. 6 as bar diagram. The results indicated that the complexes have shown smaller zone of inhibition than the standard drug (kanamycin), this implies that the complexes are less sensitive to the organisms than the standard drug. The data indicate that the complexes demonstrated stronger activity than the free ligand [2,28], indicating that coordination with this metal ions has enhanced the biological potential of the ligand. Specially, the $\mathrm{Cu}$ (II) complex (3), showed moderate to strong activity, while the zinc(II) complex (4), showed resistance against S. aureous, and $S$. lutea. The palladium(II) complex (5), showed moderate activity against $E$. coli. These values are comparable many similar bis-chelated metal(II) complexes of dithiocarbazate ligands [32,33]. However, the reason behind the increased or decreased antibacterial activity of complexes compared to the free ligand was studied extensively [3,32,34-36]. Therefore, further study is required to establish the structure activity relationship.

Table 1. Antibacterial profile of compound (1-5) in terms ofthe inhibition zone (mm).

\begin{tabular}{llllll}
\hline \multirow{2}{*}{ Compounds } & $\begin{array}{l}\text { Conc. } \\
\left(\mu \mathrm{g} \mathrm{disc}^{-1}\right)\end{array}$ & \multicolumn{2}{l}{ Gram-positive } & \multicolumn{2}{c}{ Gram-negative } \\
\cline { 3 - 6 } & & S. a. & S. l. & E. c. & S. d. \\
\hline 1 & & 10 & 9 & 10 & 10 \\
2 & 12 & 10 & 11 & - \\
3 & 200 & 13 & 12 & 14 & 13 \\
4 & & - & - & 9 & 7 \\
5 & & 11 & 12 & 13 & 9 \\
\hline Kanamycin & 30 & 25 & 30 & 25 & 28 \\
\hline "-" means no activity & & & &
\end{tabular}




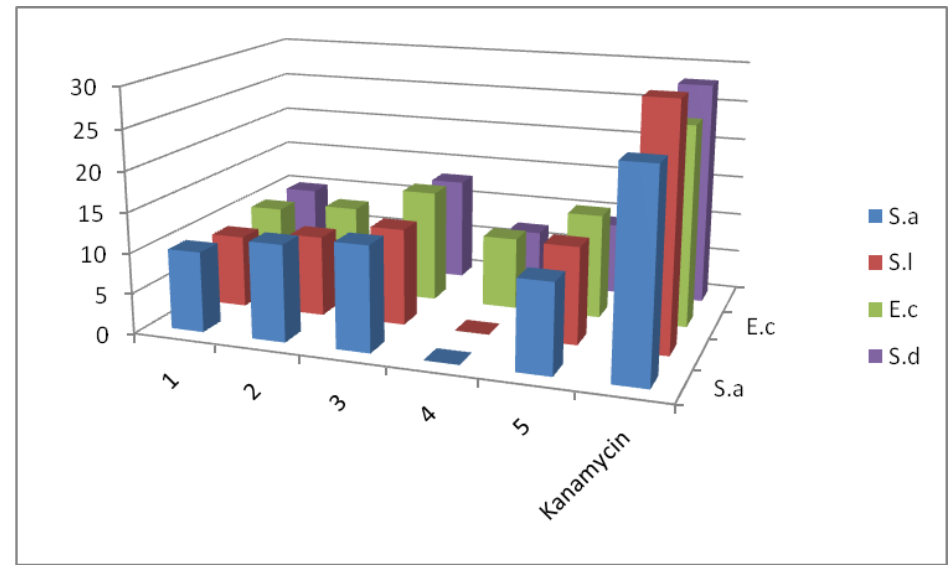

Fig. 6. Antibacterial sensitivity of compounds (1-5) in bar diagram.

\subsection{Proposed structure of complexes}

$$
\text { ethanol }
$$

Scheme 1. Preparation of Schiff base and its complexes (1-5). 


\section{Conclusion}

The ligand, S-benzyl- $\beta$ - $N$-(4-benzyloxyphenyl)methylenedithiocarbazate (1), exsist in thionetautomeric form both in the solid state and in solution. It underwent thioltautomerism followed by deprotonation and subsequent coordination with the metal ions resulting in bis-chelated $\mathrm{ML}_{2}$ complexes. The Schiff base bonded with the metal ions as uni-negative bi-dentate mode, there by forming four coordinate inner complexes. Both the ligand and its complexes showed moderate antibacterial activity.

\section{Acknowledgment}

The authors (MHI and MAAAAI) acknowledge Department of Chemistry, Rajshahi University of Engineering \& Technology for laboratory facilities for this work. MC Sheikh is grateful to Department of Applied Chemistry, University of Toyama, Japan to provide analytical facilities.

\section{References}

1. T. Curtius and K. Heidenreich, J. Prak. Chem. 52, 454 (1895). https://doi.org/10.1002/prac. 18950520135

2. M. A. A. A. A. Islam, M. C. Sheikh, M. S. Alam, E. Zangrando, M. A. Alam, M. T. H. Tarafder and R. Miyatake, Trans. Met. Chem. 39, 141 (2014). https://doi.org/10.1007/s11243-013-9783-8

3. M. S. Hossain, C. M. Zakaria, and M. K. Zahan, J. Sci. Res. 9, 209 (2017). http://dx.doi.org/10.3329/jsr.v9i2.29780

4. A. Garoufis, S. K. Hadjikakou, and N. Hadjiliadis, Coord. Chem. Rev. 253, 1384 (2009). https://doi.org/10.1016/j.ccr.2008.09.011

5. Ahmed M. Naglah, Hassan M. Awad, M. A. Bhat, M. A. Al-Omar, and Abd El-Galil E. Amer, J. Chem. 2015, Article ID 364841 (2015). https://doi.org/10.1155/2015/364841

6. F. N. F. How, K. A. Crouse, M. I. M. Tahir, M. T. H. Tarafder, and A. R. Cowley, Polyhedron 27, 3325 (2008). https://doi.org/10.1016/j.poly.2008.07.022

7. N. Bharti, M. R. Maurya, F. Naqvi, A. Bhattacharya, S. Bhattacharya, and A. Azam, Eur. J. Med. Chem. 35, 481 (2000). https://doi.org/10.1016/S0223-5234(00)00145-8

8. N. Bharti, F. Shailendra, F. Naqvi, and A. Azam, Helv. Chim. Acta 85, 2713 (2002).

9. M. R. Maurya, A. Kumar, A. R. Bhat, A. Azam, C. Bader, and D. Rehder, Inorg. Chem. 45, 1260 (2006). https://doi.org/10.1021/ic050811

10. A. B. Beshir, S. K. Guchhait, J. A. Gascón, and G. Fenteany, Bioorg. Med. Chem. Lett. 18, 498 (2008). https://doi.org/10.1016/j.bmcl.2007.11.099

11. Z. D. Liu, X. J. Zhang, J. Y. Wu, F. Y. Hao, H. P. Zhou, and Y. P. Tian, Polyhedron, 30, 279 (2011). https://doi.org/10.1016/j.poly.2010.10.022

12. M. A. Ali, H. J. H. Abu Bakar, A. H. Mirza, S. J. Smith, L. R. Gahan, and P. V. Bernhardt, Polyhedron, 27, 71 (2008). https://doi.org/10.1016/j.poly.2007.08.022

13. N. H. M. Salem, L. El-Sayed, and M. F. Iskander, Polyhedron, 27, 3215 (2008). https://doi.org/10.1016/j.poly.2008.07.009

14. P. Bera, C. H. Kim, and S. I. Seok, Polyhedron 27, 3433 (2008). https://doi.org/10.1016/j.poly.2008.07.039

15. P. Bera, C. H. Kim, and S. I. Seok, Solid State Sci. 12, 532 (2010). https://doi.org/10.1016/j.solidstatesciences.2009.12.020 
16. H. P. Zhou, D. M. Li, P. Wang, L. H. Cheng, Y. H. Gao, Y. M. Zhu, J. Y. Wu, Y. P. Tian, X. T. Tao, M. H. Jiang, and H. K. Fun, J. Mol. Struct. 826, 205 (2007). https://doi.org/10.1016/j.molstruc.2006.05.003

17. M. Yazdanbakhsh and R. Takjoo, Struct. Chem. 19, 895 (2008). https://doi.org/10.1007/s11224-008-9356-1

18. M. T. H. Tarafder, M. A. Ali, Y. W. Wong, S. I. Wong, and K. A. Crouse, Synth. React. Inorg. Met. Org. Chem. 31(1), 115 (2001). https://doi.org/10.1081/SIM-100001937

19. T. H. Rakha and M. M. Bekheit, Chem. Pharm. Bull. 48, 914 (2000). https://doi.org/10.1248/cpb.48.914

20. M. A. A. A. A. Islam, M. T. H. Tarafder, M. C. Sheikh, M. A. Alam, and E. Zangrando, Trans. Met. Chem. 36, 531 (2011). https://doi.org/10.1007/s11243-011-9499-6

21. S. Roy, T. N. Mandal, A. K. Barik, S. Pal, S. Gupta, A. Hazra, R. J. Butcher, A. D. Hunter, M. Zeller, and S. K. Kar, Polyhedron. 26, 2603(2007). https://doi.org/10.1016/j.poly.2007.01.006

22. K.A. Crouse, K. B. Chew, M. T. H. Tarafder, A. Kasbollah, A. M. Ali, B. M. Yamin, and H. K Fun, Polyhedron. 23, 161(2004). https://doi.org/10.1016/j.poly.2003.09.025

23. G. F. D. Sousa, V. A. D. S. Falcomer, Y. P. Mascarenhas, J. Ellena, J. D. Ardisson, J. ValdesMartines, and S. Hernandez-Ortega, Tran. Met. Chem. 31, 753 (2006). https://doi.org/10.1007/s11243-006-0059-4

24. C. H. Lin, J. S. Yang, C. Y. Chang, S. C. Kou, M. R. Lee, and L. J. Huang, Bioorg. Med. Chem. 13, 1537 (2005). https://doi.org/10.1016/j.bmc.2004.12.026

25. A. W. Bauer, W. M. M. Kirby, J. C. Sherris, and M. Turck, Am. J. Clin. Pathol. 45, 493 (1966). https://doi.org/10.1093/ajcp/45.4_ts.493

26. E. Zangrando, M. T. Islam, M. A. A. A. A. Islam, M. C. Sheikh, M. T. H.Tarafder, R. Miyatake, R. Zahan, and M. A. Hossain, Inorg. Chim. Acta 427, 278 (2015). http://dx.doi.org/10.1016/j.ica.2014.12.014.

27. M. S. Begum, E. Zangrando, M. B. H. Howlader, M. C. Sheikh, R. Miyatake, M. M. Hossain, M. M. Alam, and M. A. Hasnat, Polyhedron 105, 56 (2016). https://doi.org/10.1016/i.poly.2015.11.046

28. M. S. Begum, E. Zangrando, M. C. Sheikh, R. Miyatake, M. B. H. Howlader, M. N. Rahman, and A. Ghosh, Trans. Met. Chem. 42, 553 (2017). https://doi.org/10.1007/s11243-017-0160-X

29. R. A. Bhat, D. Kumar, M. A. Malla, S. U. Bhat, M. S. Khan, O. Manzoor, A. Srivastava, R. A. Naikoo, M. Mohsin, and M. A. Mir, J. Mol. Struct. 1156, 280 (2018). https://doi.org/10.1016/j.molstruc.2017.11.051

30. D. A. Edwards and R. N. Hayward, Can. J. Chem. 46, 3443 (1968). https://doi.org/10.1139/v68-572

31. M. A. A. A. A. Islam, M. C. Sheikh, M. A. Mumit, R. Miyatake, M. A. Alam, and M. O. A. Mondal, J. Coord. Chem. 69, 3580 (2016). https://doi.org/10.1080/00958972.2016.1233329

32. M. L. Low, L. Maigre, P. Dorlet, R. Guillot, J. M. Pagès, K. A. Crouse, C. Policar, and N. Delsuc, Bioconjugate Chem. 25, 2269 (2014). https://doi.org/10.1021/bc5004907

33. E. Zangrando, M. S. Begum, M. C. Sheikh, R. Miyatake, M. M. Hossain, M. M. Alam, M. A. Hasnat, M. A. Halim, S. Ahmed, M. N. Rahman, and A. Ghosh, Arab. J. Chem. 10, 172 (2017).

34. M. A. Subhan, F. Ahmed, M. S. Rahaman, A. K. Azad and K. Begum, J. Sci. Res. 7, 113 (2015). http://dx.doi.org/10.3329/jsr.v7i3.23270

35. M. Shebl, J. Coord. Chem. 69, 199 (2016). http://dx.doi.org/10.1080/00958972.2015.1116688

36. T. K. Pal, M. A. Alam, J. Hossen, S. Paul, H. Ahmad, M. C. Sheikh, J. Sci. Res. 10, 291(2018). https://doi.org/10.3329/jsr.v10i3.36379 